Research article

\title{
Gas and soot formed in the dimethoxymethane pyrolysis. Soot characterization
}

\author{
Katiuska Alexandrino, Ángela Millera, Rafael Bilbao, María U. Alzueta* \\ Aragón Institute of Engineering Research (I3A), Department of Chemical and Environmental Engineering, University of Zaragoza, C/ Mariano Esquillor, s/n. 50018 Zaragoza, Spain
}

\section{ART ICLE INFO}

\section{Keywords:}

Dimethoxymethane

Pyrolysis

Gas-phase

Soot

Reactivity

Characterization

\begin{abstract}
A B S T R A C T
The many simultaneous processes occurring within in a diesel engine make difficult a thorough understanding of the mechanisms responsible for reduction of soot and/or $\mathrm{NO}_{\mathrm{X}}$ when an oxygenated compound is added to diesel fuel. Thus, in order to explore the use of oxygenated compounds as biofuels/additives, it is interesting to study their conversion under well-controlled laboratory conditions, together with kinetic studies that help to interpret and understand the reaction schemes that occur during such processes. The aim of this work has been to contribute to the knowledge of the dimethoxymethane (DMM) pyrolysis, one of the oxygenated compounds proposed in literature as alternative fuel. In this way, the influence of pyrolysis temperature (1075-1475 K) and inlet fuel concentration (33,333 and 50,000 ppm DMM) on the sooting propensity of DMM, soot reactivity and its properties is analyzed. Therefore, this work includes pyrolysis experiments under different experimental conditions, focusing on the gas-phase analysis and the soot formation, together with a gas-phase model. Additionally, the interaction of soot with $\mathrm{O}_{2}$ and with NO has been studied, and since soot properties are important on the oxidation rate, selected soot samples have been characterized by different instrumental techniques (elemental analysis, physical adsorption with $\mathrm{N}_{2}$, Transmission Electron Microscopy (TEM), X-Ray Diffraction (XRD), and Raman spectroscopy).
\end{abstract}

\section{Introduction}

Oxygenated compounds are a promising alternative to obtain diesel fuel blends through fuel reformulation in order to reduce the exhaust gas emissions, mainly particulate matter. These blends must be compatible with current vehicle technologies. Among the possible oxygenated compounds to be used polyoxymethylene dimethyl ethers, POMDMEs, with the general formula of $\mathrm{CH}_{3} \mathrm{O}\left(\mathrm{CH}_{2} \mathrm{O}\right)_{n} \mathrm{CH}_{3}$, are a suitable alternative, with dimethyl ether (DME, $\mathrm{CH}_{3} \mathrm{OCH}_{3}$ ) and dimethoxymethane (DMM, $\mathrm{CH}_{3} \mathrm{OCH}_{2} \mathrm{OCH}_{3}$ ), with $\mathrm{n}=0$ and $\mathrm{n}=1$, respectively, as the most representative ones.

Dimethoxymethane (DMM), also called methylal, presents some advantages over dimethyl ether (DME), such as its higher quantity of oxygen, lower vapor pressure, and higher solubility with diesel [1]. Moreover, DMM has a relatively high cetane number, but low compared to that of pure diesel fuel. Thus, the addition of DMM to diesel fuel decreases the cetane number, providing possibly lengthened ignition delay times.

Several engine tests have been carried out to investigate the combustion characteristics and possible decrease of soot formation, and even $\mathrm{NO}_{\mathrm{x}}$, when DMM is added to diesel fuel (e.g. [2,3]). In general, the results of those works have shown a reduction of particulate matter emissions. Moreover, to contribute to the knowledge of the DMM conversion chemistry, studies addressing the DMM oxidation at laboratory-scale, under well-characterized conditions, have also been conducted, specifically, in jet-stirred reactors [4,5], flames [6,7], flow reactors [8,9], and shock tube [10]. Dias et al. [7] developed a kinetic model in order to simulate their net DMM flames. This model took into account the formation and the consumption of C1-C10 species, as well as of the oxygenated species involved in DMM combustion. The kinetic data used in the DMM sub-mechanism were taken mainly from the work of Daly and Simmie [4]. In general, the model led to a good simulation for all species detected. The main consumption of DMM, under their flame conditions ( $\varphi=0.24$ and 1.72 , at $50 \mathrm{mbar}$ ), was found to be through $\mathrm{H}$-atom abstraction by $\mathrm{OH}, \mathrm{O}$ and $\mathrm{H}$ radicals to produce the primary radical $\mathrm{CH}_{3} \mathrm{OCH}_{2} \mathrm{OCH}_{2}$, or the secondary radical $\mathrm{CH}_{3} \mathrm{OCHOCH}_{3}$. These radicals were consumed to finally form formaldehyde through the main pathways: (i) $\mathrm{CH}_{3} \mathrm{OCH}_{2} \mathrm{OCH}_{2} \rightarrow \mathrm{CH}_{3} \mathrm{OCH}_{2} \rightarrow \mathrm{CH}_{2} \mathrm{O}$ and (ii) $\mathrm{CH}_{3} \mathrm{OCHOCH} \mathrm{CH}_{3} \mathrm{OCHO} \rightarrow \mathrm{CH}_{3} \mathrm{OCO} \rightarrow \mathrm{CH}_{3} \mathrm{O} \rightarrow \mathrm{CH}_{2} \mathrm{O}$.

\footnotetext{
* Corresponding author.

Email address: uxue@unizar.es (M.U. Alzueta)
} 
To elucidate the effects of DMM on soot precursors, the combustion of hydrocarbon/DMM mixtures has been studied in flames [11-15]. The results showed that the replacement of part of the hydrocarbon by DMM decreases the mole fractions of hydrocarbon intermediate species, which act as soot precursors. Chemical kinetic modelling showed that the addition of DMM did not change the main reaction paths for reactants conversion and formation of intermediate species. Thus, reduction of soot precursor species was attributed to the replacement of part of the hydrocarbon by the oxygenated compound or to dilution effects, while chemical interactions were not considered significant.

The capacity to form soot of the oxygenated compounds is an interesting aspect to take into account when those compounds are aimed for its use as fuels or additives in engines. However, to our knowledge, there are not works reported in literature on the quantification of soot from DMM conversion. The present work is part of the research carried out in our group on the capacity to form soot, under pyrolytic conditions, of different oxygenated compounds proposed in literature as alternative fuels, such as dimethyl carbonate (DMC) [16], 2,5-dimethylfuran (2,5-DMF) [17], 2-methylfuran (2-MF) [18], ethanol [19], and butanol isomers [20]. The present study includes experiments under well-controlled laboratory conditions in a quartz tubular flow reactor, accompanied by a gas-phase chemical kinetic modelling that helps to interpret and understand the reaction schemes that occur during the pyrolysis process. The DMM pyrolysis experiments are carried out under different operating conditions, specifically, by varying the inlet fuel concentration (33,333 and 50,000 ppm) and temperature (1075-1475 K). Furthermore, it is interesting to study the interaction of soot with typical gases present in the combustion chamber of an engine, such as oxygen and, especially, NO present in the combustion process, which could result in the simultaneous reduction of both pollutants, decreasing their emissions in the exhaust gas. In this sense, this work also addresses the experimental reactivity study of soot formed in the DMM pyrolysis towards $\mathrm{O}_{2}$ and NO. Moreover, since the influence of the soot properties on the oxidation rate has been demonstrated in studies carried out both at laboratory-scale e.g. [19,21,22] and in engines e.g. [23,24], selected soot samples have been characterized by different instrumental techniques, i.e., elemental analysis, physical adsorption with $\mathrm{N}_{2}$, Transmission Electron Microscopy (TEM), X-Ray Diffraction (XRD), and Raman spectroscopy.

\section{Experimental methodology}

\subsection{Gas and soot formation}

The DMM pyrolysis experiments are conducted in an electrically heated quartz tubular flow reactor $(45 \mathrm{~mm}$ internal diameter and $800 \mathrm{~mm}$ in length), which allows feeding of the gases by two upper entrances. The installation was designed to collect the soot at the reactor outlet and to analyze some light gases contained in the outlet gas by means gas chromatography. This installation and the experimental procedure are explained in more detail in previous works e.g. [16-19,25]. In the present work, DMM is injected in gas-phase into the reactor by using an isocratic HPLC pump and a thermally heated line. The reactor is placed vertically inside an electrically heated furnace for controlling temperature. The total inlet flow rate used is $1000 \mathrm{~mL}$ (STP)/ $\mathrm{min}$. Once the desired temperature is reached, necessary time is allowed at this temperature in order to assure steady state before the experiment starts. The heated isothermal region length (reaction zone), whose temperature is constant $\pm 5 \mathrm{~K}$, of the flow reactor is $160 \mathrm{~mm}$, and the gas residence time $\left(t_{r}\right)$ (in seconds) in the reaction zone is given by the $4168 / \mathrm{T}(\mathrm{K})$ expression. A pressure transducer connected to the inlet line measured the system pressure. The gases flowing out of the reactor are conveyed to an Agilent 6890 gas chromatograph (GC) (accuracy of $\pm 10 \mathrm{ppm}$ ), passing through the soot collection system which consists of a quartz fiber filter with a pore diameter lower than $1 \mu \mathrm{m}$. The soot remaining on the reactor walls is also collected when the experiment ends. The GC is calibrated for light gases such as $\mathrm{CO}, \mathrm{CO}_{2}, \mathrm{H}_{2}$, methane, acetylene, ethylene, ethane, methanol, dimethyl ether, methyl formate, propane, propylene, propadiene, 1,3-butadiene, isobutane, n-butane, benzene, $\mathrm{C}_{7} \mathrm{H}_{8}$, and xylene. The total time for each experiment is fixed to $3 \mathrm{~h}$, not exceeding the pressure limit of $1.3 \mathrm{~atm}$ that could disturb the functioning of the experimental set-up.

The DMM pyrolysis experiments are performed at atmospheric pressure, temperatures of $1075,1175,1275,1325,1375,1425$, and $1475 \mathrm{~K}$, and with inlet fuel concentrations of 33,333 and 50,000 ppm. These experimental conditions have been selected to be consistent with the previous DMC pyrolysis study [16] carried out by our group.

\subsection{Soot characterization}

For soot reactivity experiments and soot characterization by instrumental techniques, the soot samples undergo a thermal treatment for $1 \mathrm{~h}$ in a $\mathrm{N}_{2}$ environment, at their formation temperature, in order to eliminate the adsorbed compounds, following the procedure described in different works $[16,19,25]$.

\subsubsection{Soot reactivity}

The reactivity experiments of the thermally treated soot samples, towards $\mathrm{O}_{2}$ and $\mathrm{NO}$, are performed in an installation described in detail elsewhere e.g. [19,25,26]. Briefly, mass flow controllers are used to feed $\mathrm{N}_{2}$ and $\mathrm{O}_{2}$ or NO from gas cylinders into the reactor. $\mathrm{O}_{2}$ and $\mathrm{NO}$ are the reactant gases, while $\mathrm{N}_{2}$ is used to obtain a total flow rate of $1000 \mathrm{~mL}(\mathrm{STP}) / \mathrm{min}$. The initial $\mathrm{O}_{2}$ and $\mathrm{NO}$ concentrations used in the $\mathrm{O}_{2}$-soot and NO-soot interaction experiments (500 and $2000 \mathrm{ppm}$, respectively), as well as the temperature ( $1275 \mathrm{~K})$, have been selected to be consistent with previous studies by our group e.g. $[16,19,25]$.

\subsubsection{Soot characterization by instrumental techniques}

In order to relate the soot reactivity with its properties (composition, surface area, morphology, crystallite structure, and degree of order), several characterization techniques are used, specifically, elemental analysis, physical adsorption with $\mathrm{N}_{2}$, Transmission Electron Microscopy (TEM), X-Ray Diffraction (XRD), and Raman spectroscopy. The characterization analysis is performed for the thermally treated soot samples obtained in the pyrolysis of $33,333 \mathrm{ppm}$ of DMM at $1475 \mathrm{~K}$ (DMM33_1475), and of 50,000 ppm of DMM at 1425K (DMM50_1425) and at 1475K (DMM50_1475).

\section{Chemical kinetic model}

The numerical simulation on the DMM pyrolysis at atmospheric pressure is carried out using the Chemkin 18.0 package [27]. The gas-phase model used in our previous investigation on other oxygenated compound (DMC) pyrolysis [28] was used as the base mechanism. This base mechanism is founded on the model progressively developed in our group e.g. [29-31], to which the DMC sub-mechanism proposed by Glaude et al. [32] was added. In other work [16], the chemistry involving the formation and consumption of polycyclic aromatic hydrocarbons (PAH) [33,34] was also added to the base mechanism. This resulting mechanism [16] has been merged in the present work with the sub-mechanisms of DMM, methyl formate (MF) and dimethyl ether (DME) proposed by Dias et al. [7], Dooley et al. [35] and Alzueta et al. [36], respectively. This final gas-phase model was used without further modifications. The thermodynamic data are taken from the same sources as the original reaction subsets. The full model (306 chemical species and 1295 reactions), as well as the thermodynamic data, are provided in the Supplementary material. 


\section{Results and discussion}

\subsection{Products formation}

Fig. 1 shows the experimental and calculated DMM conversion $\left(\mathrm{X}_{\mathrm{DMM}}\right)$ for each temperature $(1075,1175,1275,1325,1375,1425$ and $1475 \mathrm{~K})$ and inlet DMM concentration (33,333 and 50,000 ppm) studied. Model simulations cover a wider temperature range compared to the experimental data, and show that DMM starts to be converted around $800 \mathrm{~K}$, reaching a total conversion at above $975 \mathrm{~K}$. Thus, DMM is totally consumed in the whole experimental temperature range studied.

Model calculations indicate that the main paths for DMM $\left(\mathrm{CH}_{3} \mathrm{OCH}_{2} \mathrm{OCH}_{3}\right)$ consumption, in the early stage of the pyrolysis process, are the $\mathrm{H}$-atom abstraction reactions at the central carbon (reaction R1) or at the primary carbon (reaction R2).

$$
\begin{aligned}
& \mathrm{CH}_{3} \mathrm{OCH}_{2} \mathrm{OCH}_{3} \\
& +\mathrm{CH}_{3} / \mathrm{H} \rightleftarrows \mathrm{CH}_{3} \mathrm{OCHOCH}_{3}+\mathrm{CH}_{4} / \mathrm{H}_{2} \\
& \mathrm{CH}_{3} \mathrm{OCH}_{2} \mathrm{OCH}_{3} \\
& \quad+\mathrm{CH}_{3} / \mathrm{H} \rightleftarrows \mathrm{CH}_{3} \mathrm{OCH}_{2} \mathrm{OCH}_{2}+\mathrm{CH}_{4} / \mathrm{H}_{2}
\end{aligned}
$$

Thus, the formed $\mathrm{CH}_{3} \mathrm{OCHOCH}$ and $\mathrm{CH}_{3} \mathrm{OCH}_{2} \mathrm{OCH}_{2}$ radicals dissociate via $\beta$ scission to produce formaldehyde $\left(\mathrm{CH}_{2} \mathrm{O}\right)$ (R3-R6 and R7-R8, respectively), which is converted, via $\mathrm{H}$-atom abstraction, to formyl radicals (HCO) (reaction R9) to finally give $\mathrm{CO}$ (reaction R10).

$$
\begin{aligned}
& \mathrm{CH}_{3} \mathrm{OCHOCH}_{3} \rightleftarrows \mathrm{CH}_{3} \mathrm{OCHO}+\mathrm{CH}_{3} \\
& \mathrm{CH}_{3} \mathrm{OCHO}(+\mathrm{M}) \rightleftarrows \mathrm{CH}_{3} \mathrm{OH}+\mathrm{CO}(+\mathrm{M}) \\
& \mathrm{CH}_{3} \mathrm{OH}+\mathrm{H} \rightleftarrows \mathrm{CH}_{2} \mathrm{OH}+\mathrm{H}_{2} \\
& \mathrm{CH}_{2} \mathrm{OH}(+\mathrm{M}) \rightleftarrows \mathrm{CH}_{2} \mathrm{O}+\mathrm{H}(+\mathrm{M}) \\
& \mathrm{CH}_{3} \mathrm{OCH}_{2} \mathrm{OCH}_{2} \rightleftarrows \mathrm{CH}_{3} \mathrm{OCH}_{2}+\mathrm{CH}_{2} \mathrm{O} \\
& \mathrm{CH}_{3} \mathrm{OCH} \mathrm{OCH}_{2} \rightleftarrows \mathrm{CH}_{3}+\mathrm{CH}_{2} \mathrm{O} \\
& \mathrm{CH}_{2} \mathrm{O}+\mathrm{CH}_{3} \rightleftarrows \mathrm{HCO}+\mathrm{CH}_{4} \\
& \mathrm{HCO}(+\mathrm{M}) \rightleftarrows \mathrm{H}+\mathrm{CO}(+\mathrm{M})
\end{aligned}
$$

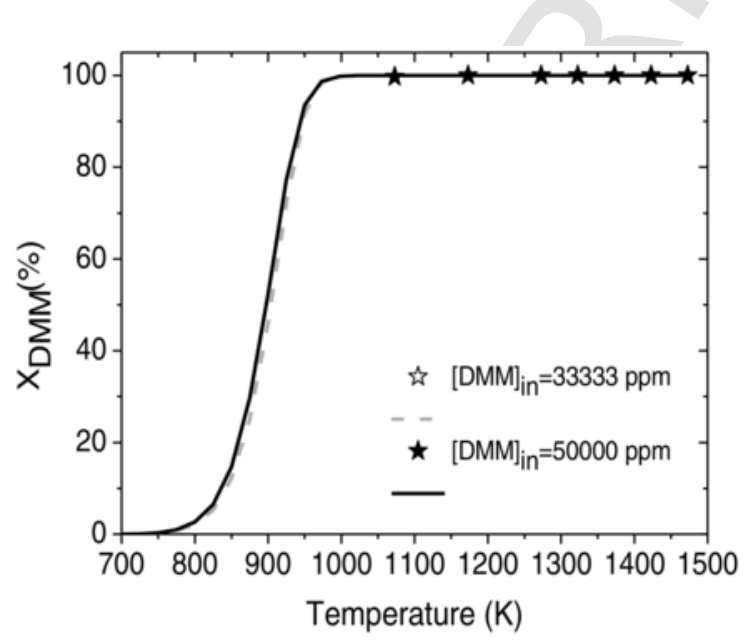

Fig. 1. DMM conversion, as a function of temperature, in the pyrolysis of 33,333 and 50,000 ppm of DMM. Experimental data (symbols), simulations (lines).
Fig. 2a shows the experimental gas yields (\%), as a function of temperature, for the two inlet DMM concentrations studied. Gas yield is defined as the percentage of the carbon amount in outlet gases related to the carbon amount fed into the reactor [19]. As it can be seen, the gas yield decreases as the temperature increases, especially above $1375 \mathrm{~K}$, because when soot formation is enhanced (fact that will be analyzed later in Fig. 3), the availability of carbon to take part in the formation of gas products decreases.

Fig. 2b)-h) show the experimental and calculated concentration values, as a function of temperature, of the main gases quantified, for both inlet DMM concentrations. In general, model calculations agree well with the experimental trends.

Ethylene (Fig. 2b) is formed through the $\mathrm{CH}_{3} \mathrm{OCH}_{2} \mathrm{OCH}_{3} \rightarrow \mathrm{CH}_{3} \mathrm{OCHOCH}_{3} \rightarrow \mathrm{CH}_{3} \rightarrow \mathrm{C}_{2} \mathrm{H}_{6} \rightarrow \mathrm{C}_{2} \mathrm{H}_{5} \rightarrow \mathrm{C}_{2} \mathrm{H}_{4}$ reaction sequence. Its concentration exhibits a maximum at $1175 \mathrm{~K}$, and above this temperature ethylene is consumed to produce acetylene with vinyl radicals $\left(\mathrm{C}_{2} \mathrm{H}_{3}\right)$ as intermediate. Fig. $2 \mathrm{c}$ indicates that the experimental acetylene concentration seems to present a maximum around $1325 \mathrm{~K}$, which is more accentuated in the simulation. Model calculations indicate that $\mathrm{C}_{2} \mathrm{H}_{2}$ conversion involves the formation of vinylacetylene $\left(\mathrm{C}_{4} \mathrm{H}_{4}\right)$, which can react with vinyl radicals or with more acetylene to form benzene, and can also participate in PAH formation at higher temperatures.

Benzene concentration peaks at 1375-1425 K (Fig. 2d). The model reproduces quite well this maximum, and indicates that this consumption is to form, by $\mathrm{H}$-atom abstraction, phenyl radicals $\left(\mathrm{C}_{6} \mathrm{H}_{5}\right)$ which could react with $\mathrm{C}_{4} \mathrm{H}_{4}$ to originate naphthalene by releasing $\mathrm{H}$ atoms.

Hydrogen (Fig. 2e) and methane (Fig. 2f) are mainly formed by the loss of an $\mathrm{H}$ atom from the central carbon or the primary carbon of DMM $\left(\mathrm{CH}_{3} \mathrm{OCH}_{2} \mathrm{OCH}_{3}+\mathrm{CH}_{3} / \mathrm{H} \rightleftarrows \mathrm{CH}_{3} \mathrm{OCHOCH}_{3}+\mathrm{CH}_{4} / \mathrm{H}_{2}\right.$ (R1) and $\mathrm{CH}_{3} \mathrm{OCH}_{2} \mathrm{OCH}_{3}+\mathrm{CH}_{3} / \mathrm{H} \rightleftarrows \mathrm{CH}_{3} \mathrm{OCH}_{2} \mathrm{OCH}_{2}+\mathrm{CH}_{4} / \mathrm{H}_{2}$ (R2), respectively). The experimental $\mathrm{H}_{2}$ concentration increases with increasing temperature. The model reproduces this trend, even though it overpredicts the experimental concentration values. The experimental $\mathrm{CH}_{4}$ concentration decreases throughout the temperature range studied, and the model predicts well the experimental data. Because $\mathrm{CH}_{4}$ is fairly unreactive under the conditions of the present work, its concentration reduction may occur because methyl radicals are involved at high temperatures in the reaction pathways leading to soot formation, instead of producing $\mathrm{CH}_{4}$, as it occurs at low temperatures.

$\mathrm{CO}$ (Fig. 2g) is formed in high amounts, and this is an indication that the carbon present in $\mathrm{CO}$ is not participating in the formation of aromatic compounds and soot. The experimental and calculated CO concentrations remain practically constant over the temperature range studied, although the model overpredicts the experimental values. According to model calculations, $\mathrm{CO}$ can be produced from DMM through paths (1) and (2).

$$
\begin{aligned}
& \mathrm{CH}_{3} \mathrm{OCH}_{2} \mathrm{OCH}_{3} \\
& \rightarrow \mathrm{CH}_{3} \mathrm{OCHOCH}_{3} \\
& \rightarrow \mathrm{CH}_{3} \mathrm{OCHO} \\
& \rightarrow \mathrm{CH}_{3} \mathrm{OH}+\mathrm{CO} \\
& \rightarrow \mathrm{CH}_{2} \mathrm{OH} \\
& \rightarrow \mathrm{CH}_{2} \mathrm{O} \\
& \rightarrow \mathrm{HCO} \\
& \rightarrow \mathrm{CO}
\end{aligned}
$$

\section{$\mathrm{CH}_{3} \mathrm{OCH}_{2} \mathrm{OCH}_{3} \rightarrow \mathrm{CH}_{3} \mathrm{OCH}_{2} \mathrm{OCH}_{2} \rightarrow \mathrm{CH}_{3} \mathrm{OCH}_{2}-$}

$\mathrm{CO}_{2}$ (Fig. 2h) was also found in the reactor outlet stream and its concentration decreases throughout the temperature range studied. The model predicts satisfactorily the experimental data. Model calculations 

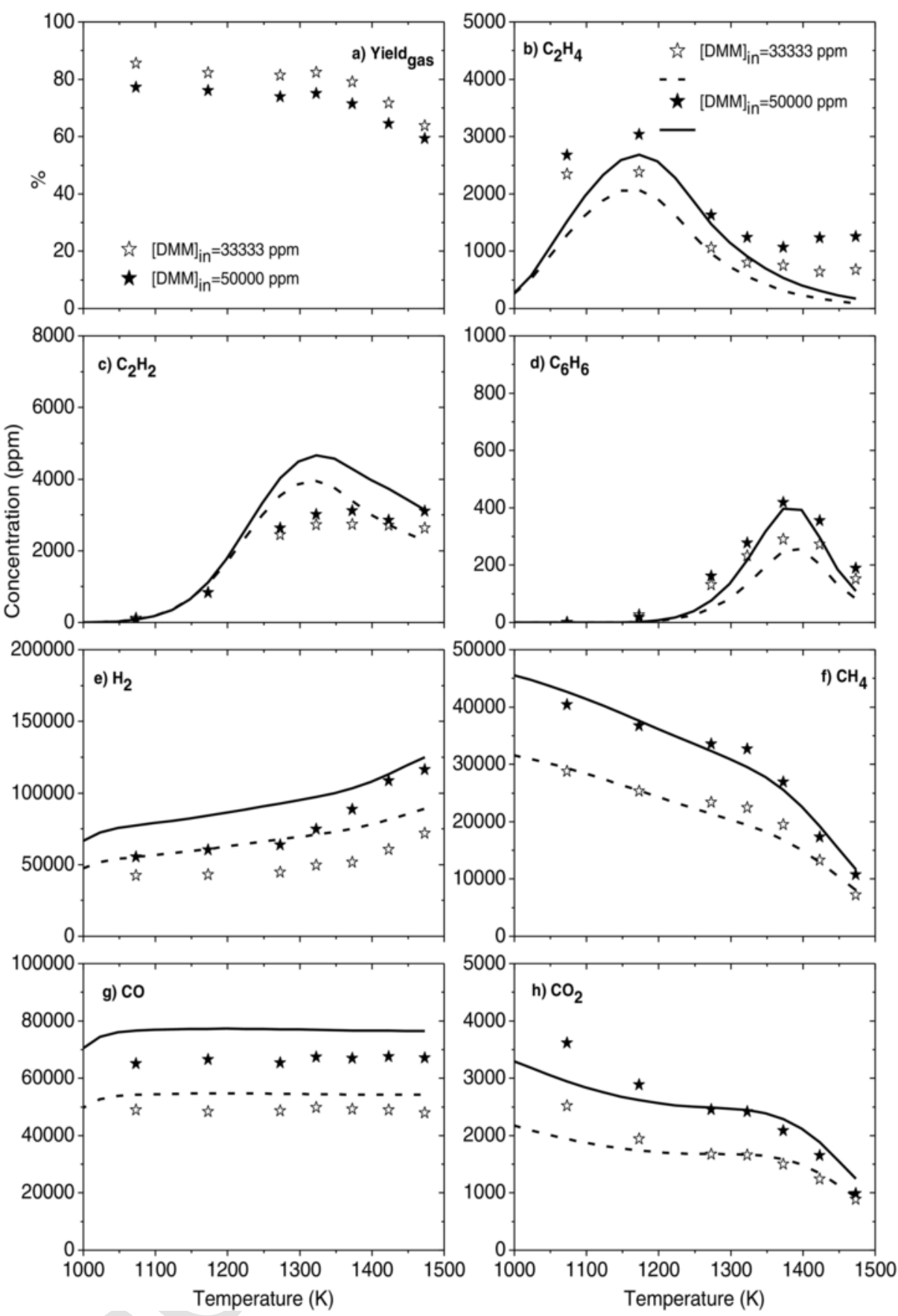

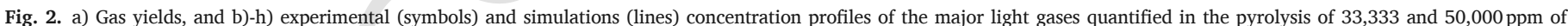
DMM, in the 975-1475 K temperature range.

show that $\mathrm{CO}_{2}$ is formed through the following reaction sequence that involves methyl formate $\left(\mathrm{CH}_{3} \mathrm{OCHO}\right)$ as intermediate:

$$
\begin{aligned}
& \mathrm{CH}_{3} \mathrm{OCH}_{2} \mathrm{OCH}_{3} \\
& \quad+\mathrm{CH}_{3} / \mathrm{H} \rightleftarrows \mathrm{CH}_{3} \mathrm{OCHOCH}_{3}+\mathrm{CH}_{4} / \mathrm{H}_{2}
\end{aligned}
$$

$\mathrm{CH}_{3} \mathrm{OCHOCH}_{3} \rightleftarrows \mathrm{CH}_{3} \mathrm{OCHO}+\mathrm{CH}_{3}$

$\mathrm{CH}_{3} \mathrm{OCHO}(+\mathrm{M}) \rightleftarrows \mathrm{CH}_{4}+\mathrm{CO}_{2}(+\mathrm{M})$

$$
\begin{aligned}
& \mathrm{CH}_{3} \mathrm{OCHO}+\mathrm{CH}_{3} / \mathrm{H} \rightleftarrows \mathrm{CH}_{3} \mathrm{OCO}+\mathrm{CH}_{4} / \mathrm{H}_{2} \\
& \mathrm{CH}_{3} \mathrm{OCO} \rightleftarrows \mathrm{CH}_{3}+\mathrm{CO}_{2}
\end{aligned}
$$

However, DMM is preferably oxidized to CO by paths (1) and (2), instead of being directly oxidized to $\mathrm{CO}_{2}$, path (3) or the sequence of reactions: R1, R3, R11-R13.

$$
\begin{aligned}
\mathrm{CH}_{3} \mathrm{OCH}_{2} \mathrm{OCH}_{3} & \rightarrow \mathrm{CH}_{3} \mathrm{OCHOCH}_{3} \\
& \rightarrow \mathrm{CH}_{3} \mathrm{OCHO} / \mathrm{CH}_{3} \mathrm{OCO} \\
& \rightarrow \mathrm{CO}_{2}
\end{aligned}
$$

(Path 3) 


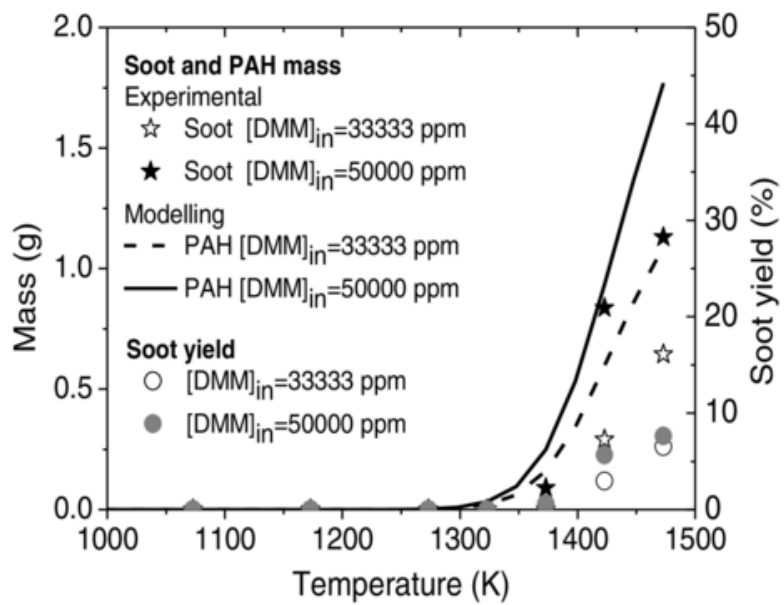

Fig. 3. Comparison of the experimental soot amounts with the total carbon mass in $\mathrm{PAH}$, calculated by modelling, and soot yields, in the pyrolysis of 33,333 and $50,000 \mathrm{ppm}$ of DMM, in the 1075-1475 K temperature range.

This last path would waste the oxygen in DMM because two $\mathrm{O}$ atoms of the fuel are attached to one carbon atom. Moreover, few species that may contribute to soot formation are formed during the DMM conversion, indicating the very low capacity of this fuel to form soot.

Fig. 3 reports the total soot amounts collected (in g) (stars) and the soot yields (in \%) (circles), as a function of temperature, for the two inlet DMM concentrations studied. The soot yield is defined as the percentage of the carbon in soot (around 98\% of the soot in mass) related to the carbon amount fed into the reactor [19].

The sum of gas (Fig. 2a) and soot (Fig. 3) yields is not 100\% because by-products, such as pyrolytic carbon, are formed and not quantified. The formation of pyrolytic carbon cannot be avoided, because it occurs through a parallel mechanism to the soot formation mechanism $[37,38]$. Moreover, the no quantification of some intermediates species, that can be produced during the pyrolysis process, may also contribute to this fact.

Fig. 3 indicates that soot is formed only at the two highest temperatures studied (1425 and $1475 \mathrm{~K}$ ). The higher the temperature and the inlet DMM concentration, the higher the soot amount and yield, because the rates of the reactions involved in the soot formation process increase $[39,40]$. This is in agreement with that observed in the pyrolysis of hydrocarbon species $[25,41]$ and other oxygenated species [16-19].

Because the proposed model does not include the prediction of the soot amount formed, and taking into account that PAH are regarded as the main soot precursors, a comparison of the experimental soot amount with the total carbon mass in PAH (up to coronene), predicted with the model, is also shown in Fig. 3. The trend of the total carbon mass in $\mathrm{PAH}$ predicted by the model is in good agreement with the experimental soot mass obtained in the DMM pyrolysis. A good agreement was also observed with the experimental soot mass obtained in the DMC pyrolysis [16]. Thus, the proposed model could be a good first approach towards a complete model including soot formation in the pyrolysis of both DMM and DMC.

It is interesting to compare the values of soot mass and yields obtained in the pyrolysis of dimethoxymethane (DMM, $\mathrm{CH}_{3} \mathrm{OCH}_{2} \mathrm{OCH}_{3}$ ) and dimethyl carbonate (DMC, $\mathrm{CH}_{3} \mathrm{OCOOCH}_{3}$ ) [16] under similar conditions. Both molecules have three carbon atoms, but the molecular structure is different. Moreover, the oxygen content in DMC is higher (53.3 wt \%) compared to DMM (42.2 wt $\%$ ).

Fig. 4 shows the results obtained for fixed inlet carbon amounts of 100,000 and $150,000 \mathrm{ppm}$, i.e., 33,333 and $50,000 \mathrm{ppm}$ of inlet fuel

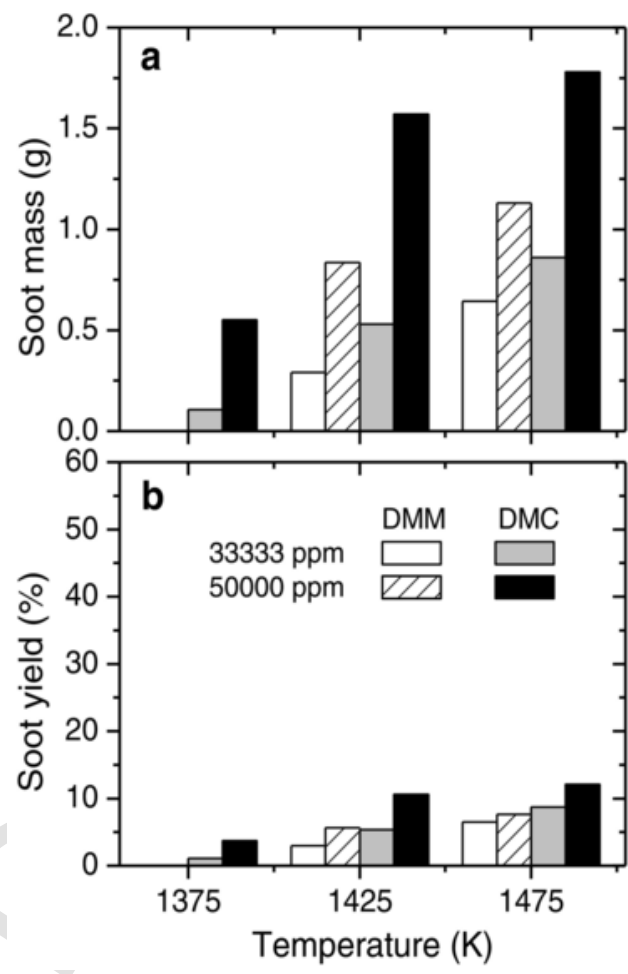

Fig. 4. Comparison of the soot mass (a) and yields (b) obtained in the pyrolysis of DMM and DMC (inlet fuel concentration of 33,333 and 50,000 ppm), at 1375, 1425 and $1475 \mathrm{~K}$.

concentration, at 1375 (which is the minimum temperature at which soot was still found in the DMC pyrolysis), 1425 and $1475 \mathrm{~K}$, and for the same residence time $\left(\mathrm{t}_{\mathrm{r}}(\mathrm{s})=4168 / \mathrm{T}(\mathrm{K})\right)$.

It is observed in Fig. 4 that, even though DMC has a higher oxygen content than DMM, DMM shows a lower capacity to form soot, throughout the temperature range studied. It is also remarkable that DMM has a lower capacity to form soot than ethanol [16]. Such fact is attributed to the specific molecular structure of DMM and DMC.

From the structure of DMM together with reactions occurring during its conversion, described earlier in the present section, and also reported in the literature e.g. [42], it can be mentioned that there are only $\mathrm{C}-\mathrm{O}$ bonds in DMM structure and, during its pyrolysis, one $\mathrm{C}-$ $\mathrm{O}$ bond is broken and the $\mathrm{O}$ atom remains bonded to another $\mathrm{C}$ atom $\left(\mathrm{CH}_{3} \mathrm{OH}+\mathrm{CO}\right.$ (reaction R4) or $\mathrm{CH}_{3} \mathrm{OCH}_{2}+\mathrm{CH}_{2} \mathrm{O}$ (reaction R7)), which means that $\mathrm{O}$ atoms in the DMM molecular structure are being used to remove carbon from the typical pathways that lead to soot formation. On the other hand, the reaction pathway associated to DMC pyrolysis [16] shows that the bond structure involving the $\mathrm{O}$ atoms leads to a direct $\mathrm{CO}_{2}$ formation, which squanders $\mathrm{O}$ atoms because two oxygen atoms are trapping a single carbon. Thus, not every $\mathrm{O}$ atom in DMC is able to eliminate a carbon atom from the soot precursor pool, and this results in a higher fraction of the remaining carbon atoms available to produce soot $[43,44]$. This behavior generally occurs with esters, and causes them to be less efficient to reduce soot formation compared to other functional group structures [45].

Fig. 5 compares the yields of $\mathrm{CO}$ and $\mathrm{CO}_{2}$ found in the pyrolysis of $33,333 \mathrm{ppm}$ of DMM and DMC from 1175 to $1475 \mathrm{~K}$. It is observed that higher $\mathrm{CO}_{2}$ concentration in the DMC pyrolysis is produced (Fig. $5 \mathrm{~b}$ ). Its high concentration in the reaction environment makes reaction R14 to proceed in the reverse sense at high temperatures (from $1375 \mathrm{~K}$ ), increasing and decreasing the yields of $\mathrm{CO}$ (Fig. 5a) and $\mathrm{CO}_{2}$ (Fig. 5b), 

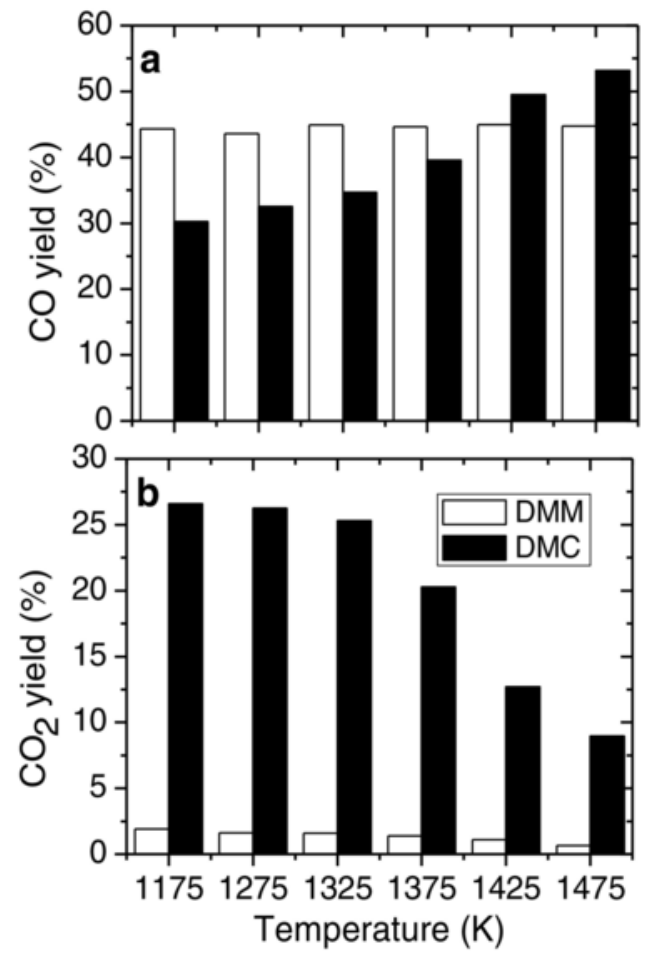

Fig. 5. Yields of $\mathrm{CO}$ and $\mathrm{CO}_{2}$ found in the pyrolysis of DMM and DMC (inlet carbon amount of $100,000 \mathrm{ppm}$ ) in the $1175-1475 \mathrm{~K}$ temperature range.

respectively.

$\mathrm{CO}+\mathrm{OH} \rightleftarrows \mathrm{CO}_{2}+\mathrm{H}$

The higher CO concentration (up to $1375 \mathrm{~K}$ ) in DMM pyrolysis compared to DMC pyrolysis (Fig. 5a) is explained because for each DMM and DMC molecule that reacts, two and one CO molecules are produced, respectively (paths (1) and (2) for DMM, and paths (3) and (4) for DMC). Above $1425 \mathrm{~K}$, the CO concentration is higher in the DMC pyrolysis, because reaction R14 occurs in the reverse sense.

$$
\begin{aligned}
& \mathrm{CH}_{3} \mathrm{OCH}_{2} \mathrm{OCH}_{3} \\
& \rightarrow \mathrm{CH}_{3} \mathrm{OCHOCH}_{3} \\
& \rightarrow \mathrm{CH}_{3} \mathrm{OCHO} \\
& \rightarrow \mathrm{CH}_{3} \mathrm{OH}+\mathbf{C O} \\
& \rightarrow \mathrm{CH}_{2} \mathrm{OH} \\
& \rightarrow \mathrm{CH}_{2} \mathrm{O} \\
& \rightarrow \mathrm{HCO} \\
& \rightarrow \mathbf{C O}
\end{aligned}
$$

(Path 1)

$$
\begin{aligned}
\mathrm{CH}_{3} \mathrm{OCH}_{2} \mathrm{OCH}_{3} & \rightarrow \mathrm{CH}_{3} \mathrm{OCH}_{2} \mathrm{OCH}_{2} \\
& \rightarrow \mathrm{CH}_{3} \mathrm{OCH}_{2}+\mathrm{CH}_{2} \mathrm{O} \\
& \rightarrow 2 \mathrm{CH}_{2} \mathrm{O} \\
& \rightarrow 2 \mathrm{HCO} \\
& \rightarrow \mathbf{2} \mathbf{C O}
\end{aligned}
$$

(Path 2)

$$
\begin{aligned}
& \mathrm{CH}_{3} \mathrm{OCOOCH}_{3} \\
& \rightarrow \mathrm{CH}_{3} \mathrm{OCOO} \\
& \rightarrow \mathrm{CH}_{3} \mathrm{O} \\
& \rightarrow \mathrm{CH}_{2} \mathrm{O} \\
& \rightarrow \mathrm{HCO} \\
& \rightarrow \mathrm{CO} \\
& \mathrm{CH}_{3} \mathrm{OCOOCH}_{3} \\
& \rightarrow \mathrm{CH}_{3} \mathrm{OCOOCH}_{2} \\
& \rightarrow \mathrm{CH}_{2} \mathrm{O} \\
& \rightarrow \mathrm{HCO} \\
& \rightarrow \mathbf{C O}
\end{aligned}
$$

(Path 3)

\subsection{Soot reactivity}

As it has been mentioned in the introduction section, it is not only important to evaluate the soot formation, but also the reactivity of the soot formed, which will determine the capacity of soot to react with surrounding gases and therefore the final emissions of soot.

Soot reactivity is analyzed, in this work, through the carbon complete conversion time $(\tau)$ values determined by fitting the experimental data for carbon conversion $\left(X_{c}\right)$ along the time to Eq. (1). This equation is obtained from the Shrinking Core Model (SCM), assuming decreasing particle size and chemical reaction control conditions [46]. This equation connects carbon conversion and time $(t)$ and has already been successfully used to describe the heterogeneous non-catalytic gas-solid reactions in similar studies carried out in our group e.g. [16,19,47].

$1-\left(1-X_{C}\right)^{1 / 3}=\frac{t}{\tau}$

A high $\tau$ value means that the carbon takes more time to complete its conversion; therefore, the soot samples with high $\tau$ values are less reactive than the soot samples with low $\tau$ values.

The carbon conversion $\left(X_{C}\right)$ is determined by Eq. (2).

$X_{c}=\frac{\left(W_{c_{0}}-W_{c}\right)}{W_{c_{0}}}$

being $W_{c 0}$ the initial reactive carbon weight, and $W_{c}$ the reactive carbon weight remaining in the reactor at a given time.

$W_{C O}$, in $\mathrm{mg}$, is calculated from the measured time evolution of $\mathrm{CO}$ and $\mathrm{CO}_{2}$ concentrations in ppm $\left(\mathrm{C}_{\mathrm{CO}}\right.$ and $\mathrm{C}_{\mathrm{CO} 2}$, respectively) of the exhaust gas by means of the following equation:

$W_{c_{0}}=10^{-3} M_{c} F_{T} \int_{0}^{\infty}\left(C_{C O}+C_{C_{2}}\right) d t$

where $M_{c}$ is the carbon atomic weight $(\mathrm{g} / \mathrm{mol})$ and $F_{T}$ is the outlet flow (mol/s).

$W_{c}$, in $\mathrm{mg}$, can be calculated through the following equation:

$W_{c}=W_{c_{0}}-10^{-3} M_{c} F_{T} \int_{0}^{t}\left(C_{C O}+C_{C O_{2}}\right) d t$

Fig. 6 represents the $\tau$ values determined in the soot- $\mathrm{O}_{2}$ and soot-NO interaction experiments at $1275 \mathrm{~K}$ of the thermally treated soot samples obtained in the DMM pyrolysis at 1425 and $1475 \mathrm{~K}$. For comparison, Fig. 6 also includes the reactivity of the soot formed in the DMC pyrolysis [16].

Soot samples are seen to be more reactive towards $\mathrm{O}_{2}$ (Fig. 6a) than to NO (Fig. 6b), even though the NO concentration in the corresponding experiments is higher than that of $\mathrm{O}_{2}(2000$ vs. $500 \mathrm{ppm})$. This result is in agreement with literature $[16,19,24,48]$, and indicates that soot formed in the combustion chamber can be oxidized in the bulk 

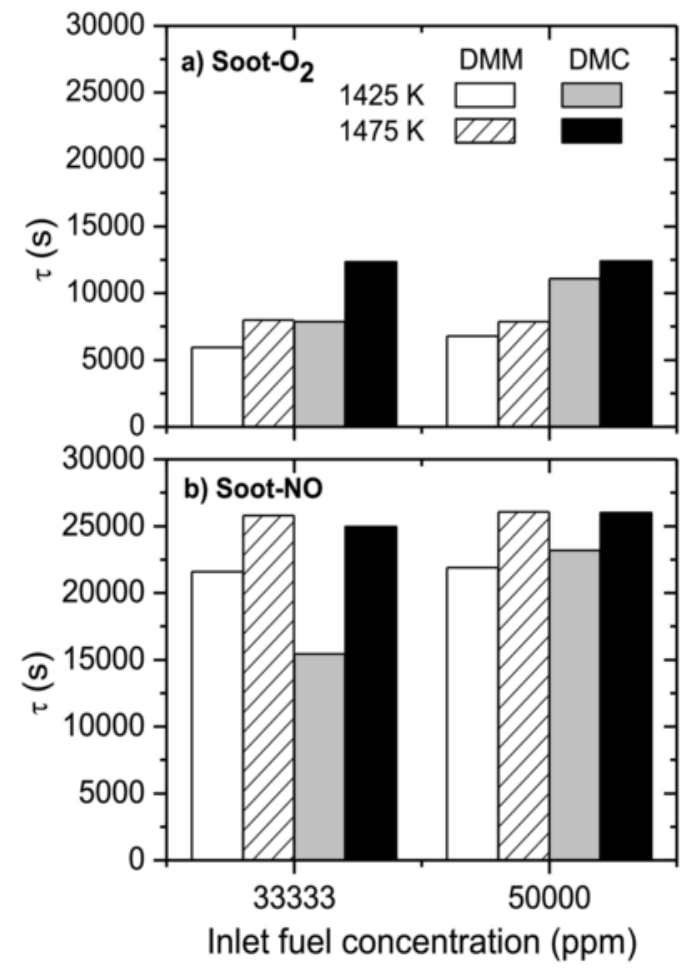

Fig. 6. Carbon complete conversion times $(\tau)$, in seconds, in the soot- $\mathrm{O}_{2}$ and soot-NO interaction experiments at $1275 \mathrm{~K}$, for soot samples obtained in the pyrolysis of 33,333 and $50,000 \mathrm{ppm}$ of DMM and DMC at 1425 and $1475 \mathrm{~K}$.

gas, mainly by $\mathrm{O}_{2}$, and hence, less soot would be emitted in the exhaust.

Regarding to the effect of the soot formation conditions on its reactivity, it is observed in Fig. 6 that the soot reactivity decreases ( $\tau$ value increases) as the soot formation temperature increases, for both soot- $\mathrm{O}_{2}$ and soot-NO interactions. Moreover, for a given temperature, the fuel concentration does not seem to have a significant influence on the soot reactivity.

Finally, it is observed in Fig. 6 that, for a given soot formation temperature, the soot formed in the DMM pyrolysis is more reactive for $\mathrm{O}_{2}$ than soot formed in the DMC pyrolysis. This trend is less clear in the soot-NO interaction.

In this sense, DMM can be considered as a good candidate to be used in engines in order to reduce soot emissions. When the DMM behavior is compared to the DMC one, it is found to exhibit a lower tendency to form soot (Fig. 4) and a higher reactivity with $\mathrm{O}_{2}$, typically present in the combustion chamber (Fig. 6).

\subsection{Soot characterization by instrumental techniques}

Table 1 lists the results of the elemental analysis of the selected thermally treated soot samples, showing that the principal component of soot samples is carbon, with a low content of hydrogen. It is known that as the atomic ratio of carbon to hydrogen $(\mathrm{C} / \mathrm{H}$ ratio) value de- creases, the soot maturity decreases, and the reactivity could be promoted. Thus, it is observed in Table 1 that, for a fixed inlet DMM concentration, the molar $\mathrm{C} / \mathrm{H}$ ratio decreases with decreasing soot formation temperature, which is consistent with that observed in reactivity experiments (Fig. 6), that the reactivity increases as the soot formation temperature decreases.

Specific and external surface areas of the selected thermally treated soot samples were determined by analyzing the isotherms obtained in the physical adsorption analysis carried out with $\mathrm{N}_{2}$ at $77 \mathrm{~K}$. In this way, the Brunauer-Emmett-Teller (BET) adsorption model [49] and the t-plot method [50] were employed, respectively. Table 2 reports the specific $\left(\mathrm{S}_{\mathrm{BET}}\right)$ and external $\left(\mathrm{S}_{\mathrm{EXT}}\right)$ surface areas for each soot sample analyzed. The soot samples show a low surface area and a limited porosity, with the soot sample formed at the lowest temperature exhibiting the higher surface area, i.e., being the most reactive, which is in agreement with the trend of reactivity experiments (Fig. 6).

The microstructure of the selected soot samples was studied by TEM. Fig. 7 shows an example of a TEM image of the DMM50_1425 soot sample. Similar images were found for the other soot samples (not shown). The particle sizes of the soot samples analyzed were found to be closer to the secondary particle sizes, i.e., $100-1000 \mathrm{~nm}$ [48]. Fig. 7 shows the typical chain-like agglomerates that form the secondary particles, which in turn are composed by several tens or hundreds of spherical or nearly-spherical particles (primary particles) that are composed of more or less ordered and amorphous domains.

Fig. 8 shows the X-ray diffractogram of the DMM50_1425 soot sample, which indicates the diffraction from the (002), (100) and (110) reflections of graphite in soot samples. In this way, information on the crystalline structure in soot samples, i.e., interlayer spacing $\left(d_{002}\right)$, the crystallite height $\left(L_{c}\right)$ and width $\left(L_{a}\right)$, and the number of layers in a crystallite $(k)$, were determined by XRD. The well-known Bragg's law (Eq. (5)), Scherrer formula (Eqs. (6) and (7)) and Eq. (8), were used to determine these structural parameters, respectively.

$d_{002}=\frac{\lambda}{2 \sin \theta_{002}}$

$L_{c}=\frac{K_{c} \lambda}{B_{002} \cos \theta_{002}}$

$L_{a}=\frac{K_{a} \lambda}{B_{100} \cos \theta_{100}}$

$k=\frac{L_{c}}{d_{002}}$

where, $\lambda$ is the wavelength (1.54 $\AA$ ), $\theta_{002}$ and $\theta_{100}$ are the Bragg's angles for (002) and (100) peaks, respectively, $K_{C}=0.9, K_{\mathrm{a}}=1.84$, and $B_{002}$ and $B_{100}$ are the FWHM (full widths at half maximum) of the (002) and (100) peaks, respectively. The Bragg's angles and FWHM are obtained by fitting the (002) and (100) peaks to two Gaussian curves. The calculated structural parameters are summarized in Table 3.

For all the soot samples, the interlayer spacing, $d_{002}$, is higher than that of pure graphite ( $3.35 \AA$ ), suggesting weaker Van der Waals forces

Table 1

Elemental analysis of the selected soot samples obtained in the DMM pyrolysis.

\begin{tabular}{|c|c|c|c|c|c|}
\hline \multicolumn{6}{|c|}{ Soot formation conditions } \\
\hline$[\mathrm{DMM}]_{\text {in }}$ & $\mathrm{T}(\mathrm{K})$ & Sample & $\mathrm{C}(\mathrm{wt} \%)$ & $\mathrm{H}(\% \mathrm{wt} \%)$ & $\mathrm{C} / \mathrm{H}$ (molar basis) \\
\hline 33,333 & 1475 & DMM33_1475 & 99.00 & 0.116 & 71.12 \\
\hline 50,000 & 1425 & DMM50_1425 & 99.00 & 0.118 & 69.91 \\
\hline 50,000 & 1475 & DMM50_1475 & 93.82 & 0.052 & 150.38 \\
\hline
\end{tabular}


Table 2

Specific $\left(\mathrm{S}_{\mathrm{BET}}\right)$ and external $\left(\mathrm{S}_{\mathrm{EXT}}\right)$ surface areas of the selected soot samples obtained in the DMM pyrolysis.

\begin{tabular}{lll}
\hline Sample & $\mathrm{S}_{\mathrm{BET}}\left(\mathrm{m}^{2} / \mathrm{g}\right)$ & $\mathrm{S}_{\mathrm{EXT}}\left(\mathrm{m}^{2} / \mathrm{g}\right)$ \\
\hline DMM33_1475 & 24.19 & 22.31 \\
DMM50_1425 & 58.07 & 44.36 \\
DMM50_1475 & 25.90 & 21.83 \\
\hline
\end{tabular}

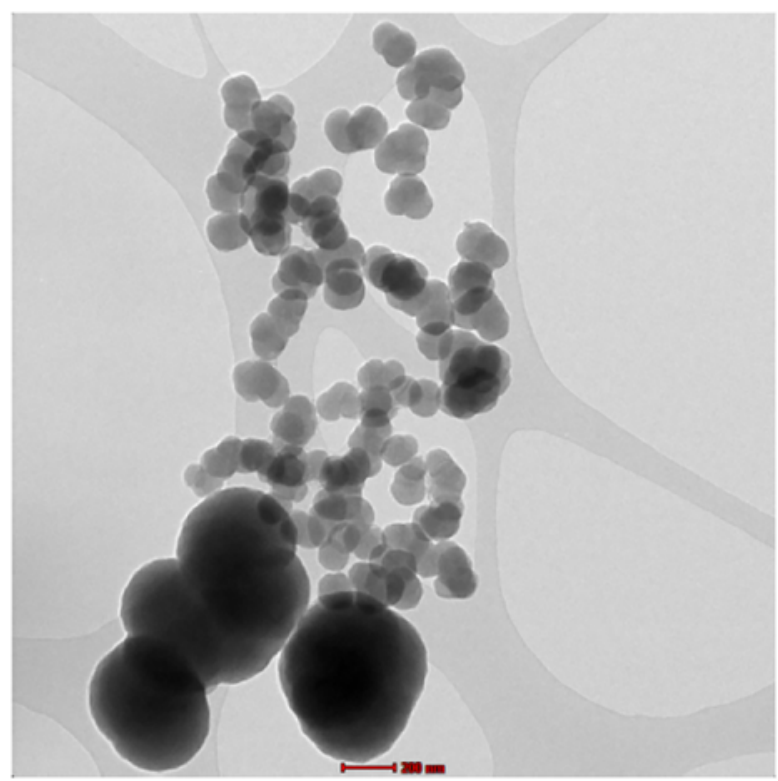

Fig. 7. TEM image of the DMM50_1425 soot sample.

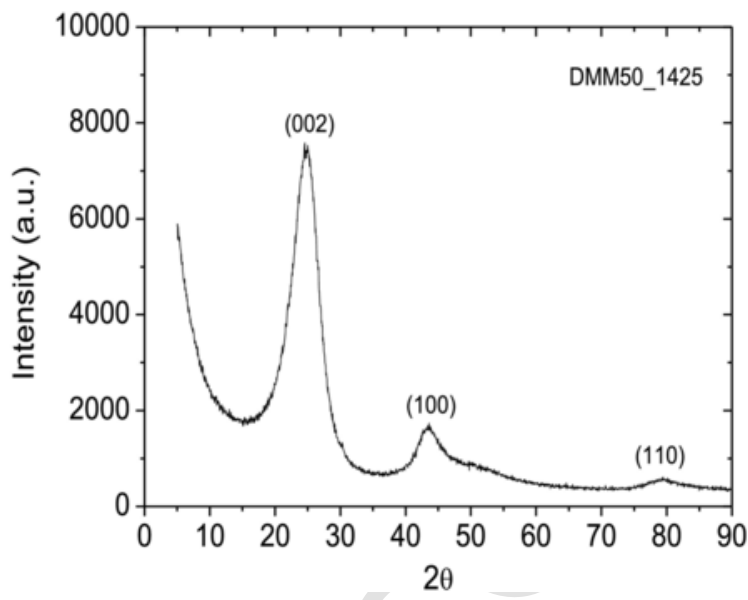

Fig. 8. X-ray diffractogram of the DMM50_1425 soot sample.

Table 3

Structural parameters of the crystalline structure determined from the analysis of the X-ray pattern of the selected soot samples obtained in the DMM pyrolysis.

\begin{tabular}{lcccl}
\hline Sample & $d_{002}(\AA)$ & $L_{c}(\AA)$ & $L_{a}(\AA)$ & $k$ (layers) \\
\hline DMM33_1475 & 3.58 & 19.08 & 45.81 & 5.34 \\
DMM50_1425 & 3.58 & 18.21 & 47.73 & 5.09 \\
DMM50_1475 & 3.55 & 24.30 & 45.76 & 6.84 \\
\hline
\end{tabular}

of attraction between the carbon layers and, consequently, a lower order. For a fixed inlet fuel concentration, $L_{C}$ decreases with decreasing soot formation temperature, which suggests the lowest order, thus the highest reactivity. This is consistent to what is observed in reactivity experiments (Fig. 6). According to literature [51], the graphitization degree increases as $L_{a}$ increases (reactivity decreases). However, this trend is not observed in the present work.

In order to assess the degree of order and the amorphous carbon content in soot particles, the Raman spectroscopy was employed. Fig. 9 shows, as an example, the first-order observed Raman spectrum of the DMM50_1425 soot sample, which has been fitted to five curves following the model proposed by Sadezky et al. [52] that includes the Lorentzian-shape bands G, D1, D2, and D4, and the Gaussian-shape band D3. This fitting allows the determination of the spectroscopic parameters, i.e., peak position, bandwidth (FWHM) and band intensity of the main Raman bands. In this way, the degree of order and the amorphous carbon content in soot particles have been determined through the $\mathrm{I}_{\mathrm{D} 1} / \mathrm{I}_{\mathrm{G}}$ and $\mathrm{I}_{\mathrm{D} 3} / \mathrm{I}_{\mathrm{G}}$ band intensity ratios (Table 4 ), with the $\mathrm{G}$ (at $\sim 1580 \mathrm{~cm}^{-1}$ ), D1 (at $\sim 1350 \mathrm{~cm}^{-1}$ ), and D3 (at $\sim 1500-1550 \mathrm{~cm}^{-1}$ ) bands representing the ideal graphitic layers, the presence of structural defects in the basal plane of the graphene layers [53], and the amorphous carbon content of soot [54], respectively. It is expected that the $\mathrm{I}_{\mathrm{D} 1} / \mathrm{I}_{\mathrm{G}}$ and $\mathrm{I}_{\mathrm{D} 3} / \mathrm{I}_{\mathrm{G}}$ band intensity ratios increase as the temperature soot formation decreases. However, it is observed in Table 4 that it is only true for the $\mathrm{I}_{\mathrm{D} 1} / \mathrm{I}_{\mathrm{G}}$ ratio.

Table 5 shows the properties values of the soot formed in the DMC pyrolysis [16], at the same experimental conditions that the soot formed in the DMM pyrolysis.

Comparing the properties of the DMM soot samples with the DMC soot samples, it can be observed that, in general, the values of $S_{\mathrm{BET}}$ and $\mathrm{I}_{\mathrm{D}} / \mathrm{I}_{\mathrm{G}}$ for DMM soot samples are higher (which would correspond to higher reactivity), while the values of the $\mathrm{C} / \mathrm{H}$ ratio and $L_{\mathrm{c}}$ are also higher (which would correspond to lower reactivity). Therefore, the relationship between reactivity and properties of soot can be considered as consistent when soot is obtained from the same fuel at different temperatures, but doubts arise when soot samples obtained from different fuels are compared.

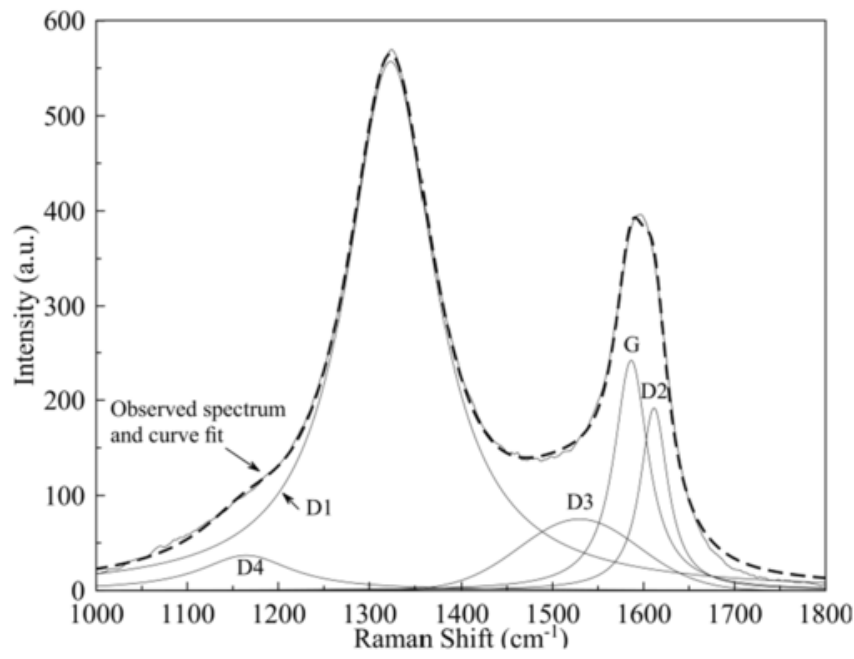

Fig. 9. First-order Raman spectrum of the DMM50_1425 soot sample with the five-curve deconvolution model proposed by Sadezky et al. [52]

Table 4

$\mathrm{I}_{\mathrm{D} 1} / \mathrm{I}_{\mathrm{G}}$ and $\mathrm{I}_{\mathrm{D} 3} / \mathrm{I}_{\mathrm{G}}$ band intensity ratios determined from the Raman spectra of the selected soot samples obtained in the DMM pyrolysis.

\begin{tabular}{lll}
\hline Sample & $\mathrm{I}_{\mathrm{D} 1} / \mathrm{I}_{\mathrm{G}}$ & $\mathrm{I}_{\mathrm{D} 3} / \mathrm{I}_{\mathrm{G}}$ \\
\hline DMM33_1475 & 1.94 & 0.53 \\
DMM50_1425 & 2.30 & 0.31 \\
DMM50_1475 & 2.28 & 0.52 \\
\hline
\end{tabular}




\begin{tabular}{|c|c|c|c|c|c|c|}
\hline \multirow[b]{2}{*}{ Sample } & \multirow{2}{*}{$\begin{array}{l}\text { C } \\
\text { (\% wt.) }\end{array}$} & \multirow{2}{*}{$\begin{array}{l}\mathrm{H} \\
\text { (\% wt.) }\end{array}$} & \multirow{2}{*}{$\begin{array}{l}\mathrm{C} / \mathrm{H} \\
\text { (molar basis) }\end{array}$} & \multirow{2}{*}{$\begin{array}{l}\mathrm{S}_{\mathrm{BET}} \\
\left(\mathrm{m}^{2} / \mathrm{g}\right)\end{array}$} & \multirow{2}{*}{$\begin{array}{l}L_{c} \\
(\AA)\end{array}$} & \multirow{2}{*}{$\mathrm{I}_{\mathrm{D}} / \mathrm{I}_{\mathrm{G}}$} \\
\hline & & & & & & \\
\hline DMC3_1475 & 97.92 & 0.37 & 21.99 & 27.27 & 18.22 & 1.35 \\
\hline DMC5_1425 & 97.91 & 0.45 & 18.14 & 32.88 & 16.82 & 1.40 \\
\hline DMC5_1475 & 98.54 & 0.34 & 23.80 & 19.00 & 18.43 & 1.19 \\
\hline
\end{tabular}

\section{Conclusions}

An experimental and modelling study on the dimethoxymethane (DMM) pyrolysis at atmospheric pressure was carried out using a tubular flow reactor, with 33,333 and $50,000 \mathrm{ppm}$ inlet fuel concentrations, and in the $1075-1475 \mathrm{~K}$ temperature range. Some of the light gases formed were experimentally quantified and a detailed kinetic model was proposed to describe the gas-phase process, while the capacity to form soot of DMM was analyzed through the experimental quantification of soot. Additionally, the characterization of the soot formed in the DMM pyrolysis was carried out through reactivity experiments at $1275 \mathrm{~K}$ towards $\mathrm{O}_{2}(500 \mathrm{ppm})$ and $\mathrm{NO}(2000 \mathrm{ppm})$ and by several instrumental techniques, such as, elemental analysis, physical adsorption with $\mathrm{N}_{2}$, Transmission Electron Microscopy (TEM), X-Ray Diffraction (XRD), and Raman spectroscopy.

Regarding to the pyrolysis experiments, it was observed that DMM is totally consumed in the whole experimental temperature range studied. As the temperature increased, the gas yield decreased and the soot yield increased. Simulations of the gas-phase showed good agreement with the experimental data trends. The $\mathrm{H}$-atom abstraction, by reactions at the central carbon or at the primary carbon, to give the $\mathrm{CH}_{3} \mathrm{OCHOCH}_{3}$ and $\mathrm{CH}_{3} \mathrm{OCH}_{2} \mathrm{OCH}_{2}$ radicals, respectively, which ultimately form $\mathrm{CO}$ throughout a series of reactions that involves formaldehyde and formyl radicals as intermediates, was found to be the main path for the DMM consumption. Moreover, a comparison of the experimental soot mass with the calculated total carbon mass in PAH (up to coronene) was performed showing that the proposed model could be a first approach towards a model including soot formation. On the other hand, reactivity results showed that all soot samples were more reactive towards $\mathrm{O}_{2}$ than to NO, with soot samples formed at lower temperatures being more reactive than the soot formed at higher temperatures, while the inlet fuel concentration in the soot formation seems to have no significant influence on the soot reactivity. The characterization by instrumental techniques revealed that, in general, samples with low $\mathrm{C} / \mathrm{H}$ ratio, high surface area, low crystallite size, and low degree of organization were more reactive.

The results obtained indicate that DMM is a good candidate to be used in engines in order to reduce soot emissions. When the DMM behavior is compared to the DMC one, which has higher oxygen content, DMM presents a lower tendency to form soot and higher reactivity, mainly towards $\mathrm{O}_{2}$.

\section{Acknowledgement}

Authors are grateful for the financial support from the Aragón Government and European Social Fund (GPT group), and MINECO and FEDER (Project CTQ2015-65226). Ms. K. Alexandrino acknowledges to MINECO the pre-doctoral grant awarded (BES-2013-063049).

\section{Appendix A. Supplementary data}

Supplementary data to this article can be found online at https:// doi.org/10.1016/j.fuproc.2018.07.021.

\section{References}

[1] C. Zhang, P. Li, Y. Li, J. He, X. Li, Shock-tube study of dimethoxymethane ignition at high temperatures, Energy Fuel 28 (2014) 4603-4610.

[2] M.M. Maricq, R.E. Chase, D.H. Podsiadlik, W.O. Siegl, E.W. Kaiser, The effect of dimethoxymethane additive on diesel vehicle particulate emissions, In: SAE Technical Paper 982572, 1998.

[3] R. Zhu, X. Wang, H. Miao, Z. Huang, J. Gao, D. Jiang, Performance and emission characteristics of diesel engines fueled with diesel-dimethoxymethane (DMM) blends, Energy Fuel 23 (2009) 286-293.

[4] C.A. Daly, J.M. Simmie, Oxidation of dimethoxymethane in a jet-stirred reactor, Combust. Flame 125 (2001) 1106-1117.

[5] W. Sun, T. Tao, M. Lailliau, N. Hansen, B. Yang, P. Dagaut, Exploration of the oxidation chemistry of dimethoxymethane: jet-stirred reactor experiments and kinetic modeling, Combust. Flame 193 (2018) 491-501.

[6] A. Sinha, M.J. Thomson, The chemical structures of opposed flow diffusion flames of C3 oxygenated hydrocarbons (isopropanol, dimethoxymethane, and dimethylcarbonate) and their mixtures, Combust. Flame 136 (2004) 548-556.

[7] V. Dias, X. Lories, J. Vandooren, Lean and rich premixed dimethoxymethane/oxygen/argon flames: experimental and modeling, Combust. Sci. Technol. 182 (2010) $350-364$.

[8] L. Marrodán, E. Royo, Á. Millera, R. Bilbao, M.U. Alzueta, High pressure oxidation of dimethoxymethane, Energy Fuel 29 (2015) 3507-3517.

[9] L. Marrodán, F. Monge, Á. Millera, R. Bilbao, M.U. Alzueta, Dimethoxymethane oxidation in a flow reactor, Combust. Sci. Technol. 188 (2016) 719-729.

[10] C. Zhang, P. Li, Y. Li, J. He, X. Li, Shock-tube study of dimethoxymethane ignition at high temperatures, Energy Fuel 28 (2014) 4603-4610.

[11] C. Renard, P.J.V. Tiggelen, J. Vandooren, Effect of dimethoxymethane addition on the experimental structure of a rich ethylene/oxygen/argon flame, Proc. Combust. Inst. 29 (2003) 1277-1284.

[12] C. Renard, P.J.V. Tiggelen, J. Vandooren, Comparison of the effect of dimethoxymethane (DMM) or diethoxymethane (DEM) addition in a rich ethylene-oxygen-argon flame on soot precursors depletion, In: Proceedings of the European Combustion Meeting, 2005.

[13] V. Dias, J. Vandooren, Experimental and modeling studies of $\mathrm{C}_{2} \mathrm{H}_{4} / \mathrm{O}_{2} / \mathrm{Ar}$, $\mathrm{C}_{2} \mathrm{H}_{4} /$ methylal $/ \mathrm{O}_{2} / \mathrm{Ar}$ and $\mathrm{C}_{2} \mathrm{H}_{4} /$ ethylal $/ \mathrm{O}_{2} / \mathrm{Ar}$ rich flames and the effect of oxygenated additives, Combust. Flame 158 (2011) 848-859.

[14] G. Chen, W. Yu, J. Fu, J. Mo, Z. Huang, J. Yang, Z. Wang, H. Jin, F. Qi, Experimental and modeling study of the effects of adding oxygenated fuels to premixed n-heptane flames, Combust. Flame 159 (2012) 2324-2335.

[15] W. Sun, B. Yang, N. Hansen, K. Moshammer, The influence of dimethoxy methane (DMM)/dimethyl carbonate (DMC) addition on a premixed ethane/oxygen/argon flame, Proc. Combust. Inst. 36 (2017) 449-457.

[16] K. Alexandrino, J. Salinas, Á. Millera, R. Bilbao, M.U. Alzueta, Sooting propensity of dimethyl carbonate, soot reactivity and characterization, Fuel 183 (2016) 64-72.

[17] K. Alexandrino, P. Salvo, Á. Millera, R. Bilbao, M.U. Alzueta, Influence of the temperature and 2,5-dimethylfuran concentration on its sooting tendency, Combust. Sci. Technol. 188 (2016) 651-666.

[18] K. Alexandrino, C. Baena, Á. Millera, R. Bilbao, M.U. Alzueta, 2-methylfuran pyrolysis: gas-phase modelling and soot formation, Combust. Flame 188 (2018) 376-387.

[19] C. Esarte, M. Peg, M.P. Ruiz, Á. Millera, R. Bilbao, M.U. Alzueta, Pyrolysis of ethanol: gas and soot products formed, Ind. Eng. Chem. Res. 50 (2011) 4412-4419.

[20] F. Viteri, S. Gracia, Á. Millera, R. Bilbao, M.U. Alzueta, Polycyclic aromatic hydrocarbons (PAHs) and soot formation in the pyrolysis of the butanol isomers, Fuel 197 (2017) 348-358.

[21] R.L. Vander Wal, A.J. Tomasek, Soot oxidation: dependence upon initial nanostructure, Combust. Flame 134 (2003) 1-9.

[22] R.L. Vander Wal, A.J. Tomasek, Soot nanostructure: dependence upon synthesis conditions, Combust. Flame 136 (2004) 129-140.

[23] H.J. Seong, A.L. Boehman, Impact of intake oxygen enrichment on oxidative reac tivity and properties of diesel soot, Energy Fuel 25 (2011) 602-616. 
[24] S. Bagi, V. Sharma, M. Patel, P.B. Aswath, Effects of diesel soot composition and accumulated vehicle mileage on soot oxidation characteristics, Energy Fuel 30 (2016) 8479-8490.

[25] M.P. Ruiz, A. Callejas, Á. Millera, M.U. Alzueta, R. Bilbao, Soot formation from $\mathrm{C}_{2} \mathrm{H}_{2}$ and $\mathrm{C}_{2} \mathrm{H}_{4}$ pyrolysis at different temperatures, J. Anal. Appl. Pyrolysis 79 (2007) 244-251.

[26] C. Arnal, M.U. Alzueta, Á. Millera, R. Bilbao, Influence of water vapor addition on soot oxidation at high temperature, Energy 43 (2012) 55-63.

[27] ANSYS Chemkin 18.0, 15151, ANSYS Reaction Design: San Diego, 2016.

[28] M.U. Alzueta, P. Salinas, Á. Millera, R. Bilbao, M. Abián, A study of dimethyl carbonate conversion and its impact to minimize soot and NO emissions, Proc. Combust. Inst. 36 (2017) 3985-3993.

[29] P. Glarborg, M.U. Alzueta, K. Dam-Johansen, J.A. Miller, Kinetic modeling of hydrocarbon/nitric oxide interactions in a flow reactor, Combust. Flame 115 (1998) $1-27$.

[30] M. Abián, C. Esarte, Á. Millera, R. Bilbao, M.U. Alzueta, Oxidation of acetylene-ethanol mixtures and their interaction with NO, Energy Fuel 22 (2008) 3814-3823.

[31] M. Abián, J. Giménez-López, R. Bilbao, M.U. Alzueta, Effect of different concentration levels of $\mathrm{CO}_{2}$ and $\mathrm{H}_{2} \mathrm{O}$ on the oxidation of $\mathrm{CO}$ : experiments and modeling, Proc. Combust. Inst. 33 (2011) 317-323.

[32] P.A. Glaude, W.J. Pitz, M.J. Thomson, Chemical kinetic modeling of dimethyl carbonate in an opposed-flow diffusion flame, Proc. Combust. Inst. 30 (2005) $1111-1118$.

[33] J. Appel, H. Bockhorn, M. Frenklach, Kinetic modeling of soot formation with detailed chemistry and physics: laminar premixed flames of C2 hydrocarbons, Combust. Flame 121 (2000) 122-136.

[34] H. Richter, S. Granata, W.H. Green, J.B. Howard, Detailed modeling of PAH and soot formation in a laminar premixed benzene/oxygen/argon low-pressure flame, Proc. Combust. Inst. 30 (2005) 1397-1405.

[35] S. Dooley, M.P. Burke, M. Chaos, Y. Stein, F.L. Dryer, V.P. Zhukov, O. Finch, J.M. Simmie, H.J. Curran, Methylformate oxidation: speciation data, laminar burning velocities, ignition delay times, and validated chemical kinetic model, In. J. Chem. Kinet. 42 (2010) 527-549.

[36] M.U. Alzueta, J. Muro, R. Bilbao, P. Glarborg, Oxidation of dimethyl ether and its interaction with nitrogen oxide, Isr. J. Chem. 39 (1999) 73-86.

[37] G.L. Dong, K.J. Huttinger, Consideration of reaction mechanisms leading to pyrolytic carbon of different textures, Carbon 40 (2002) 2515-2528.

[38] A. Oberlin, Pyrocarbons, Carbon 40 (2002) 7-24.

[39] A. Alexiou, A. Williams, Soot formation in shock-tube pyrolysis of toluene-n-heptane and toluene-iso-octane mixtures, Fuel 74 (1995) 153-158.
[40] T.H. Fletcher, J. Ma, J.R. Rigby, A.L. Brown, B.W. Webb, Soot in coal combustion system, Prog. Energy Combust. Sci. 23 (1997) 283-301.

[41] N.E. Sánchez, Á. Millera, R. Bilbao, M.U. Alzueta, Polycyclic aromatic hydrocarbons (PAH), soot and light gases formed in the pyrolysis of acetylene at different temperatures: effect of fuel concentration, J. Anal. Appl. Pyrolysis 103 (2013) 126-133.

[42] C.K. Westbrook, W.J. Pitz, H.J. Curran, Chemical kinetic modeling study of the effects of oxygenated hydrocarbons on soot emissions from diesel engines, J. Phys. Chem. A 110 (2006) 6912-6922.

[43] E.J. Barrientos, M. Lapuerta, A.L. Boehman, Group additivity in soot formation for the example of C-5 oxygenated hydrocarbons fuels, Combust. Flame 160 (2013) 1484-1498.

[44] C.K. Westbrook, W.J. Pitz, H.J. Curran, Chemical kinetic modeling study of the effects of oxygenated hydrocarbons on soot emissions from diesel engines, J. Phys. Chem. A 110 (2006) 6912-6922.

[45] R. Lemaire, D. Lapalme, P. Seers, Analysis of the sooting propensity of C-4 and C-5 oxygenates: comparison of sooting indexes issued from laser-based experiments and group additivity approaches, Combust. Flame 162 (2015) 3140-3155.

[46] O. Levenspiel, Chemical Reaction Engineering, 3rd ed., Wiley, New York, 1999393-440.

[47] T. Mendiara, M.U. Alzueta, Á. Millera, R. Bilbao, Oxidation of acetylene soot: influence of oxygen concentration, Energy Fuel 21 (2007) 3208-3215.

[48] B.R. Stanmore, J.F. Brilhac, P. Gilot, The oxidation of soot: a review of experiments, mechanisms and models, Carbon 39 (2001) 2247-2268.

[49] S.J. Gregg, S.W. Sing, Adsorption, Surface Area, and Porosity, Academic Press, London, 1982.

[50] B.C. Lippens, J.H. de Boer, Studies on pore systems in catalysts: V. The t method, J. Catal. 4 (1965) 319-323.

[51] K. Al-Qurashi, A.L. Boehman, Impact of exhaust gas recirculation (EGR) on the oxidative reactivity of diesel engine soot, Combust. Flame 155 (2008) 675-695.

[52] A. Sadezky, H. Muckenhuber, H. Grothe, R. Niessner, U. Poschl, Raman microspectroscopy of soot and related carbonaceous materials: spectral analysis and structural information, Carbon 43 (2005) 1731-1742.

[53] K. Nithyanandan, Y. Lin, R. Donahue, X. Meng, J. Zhang, C.F. Lee, Characterization of soot from diesel-CNG dual-fuel combustion in a CI engine, Fuel 184 (2016) $145-152$.

[54] N.P. Ivleva, U. McKeon, R. Niessner, U. Poschl, Raman microspectroscopic analysis of size- resolved atmospheric aerosol particle samples collected with an ELPI: soot, humic-like substances, and inorganic compounds, Aerosol Sci. Technol. 41 (2007) 655-671. 